\title{
タイ王国における地理情報システムの都市計画への利用状況
}

\author{
寺木 彰浩
}

\section{Geographic Information System for Urban Planning in Thailand}

\author{
Akihiro TERAKI
}

\begin{abstract}
This paper deals with a survey concerning Geographic Information System(GIS) for Urban Planning in Thailand. The survey was done for Department of Town and Country Planning(DTCP), Bangkok Metropolitan Agency, Chulalongkorn University. The result shows that GIS for urban planning prevails in Thailand like in Japan and GIS data will be open to the public in future.
\end{abstract}

Keywords: 地理情報システム(GIS), 都市棓画(Urban Planning), タイ王国(Thailand)

\section{1.はじめに}

近年のコンピュータ関連技術の目覚しい発展に 伴って様々な分野で高度な情報処理が行なわれるよ うになってきている。都市計画の分野においてもこ の傾向は顕著であり、これまでにもわが国をはじめ 米国や豪州などにおける地理情報システム（GIS） の活用事例が報告されている。しかし、先進国のみ ならず発展途上国においてもGISの導入は積極的に 行なわれており、その実態を報告する意義は大きい ものと考える。

本稿では、発展途上国としてタイ王国を取り上 げ、1995年11月に以下の機関に行ったヒアリング調 查の成果を、筆者の責任において取りまとめた結果 について報告する。

・内務省都市農村計画局

・バンコク首都圈庁

・チュラロンコン大学

寺木：テ305 茨城県つくば市立原 1 建設省建築研究所第六部都市開発研究室 Urban Development Div., Urban Planning Dept., Buiding Research Institute, Min. of Construction 1 Tachihara, Tsukuba, Ibaraki 305, Japan Tel. 0298-64-6698

E-mail: teraki@kenken.go.jp

\section{2.タイ王国における都市計画の現状}

都市計画は本来、地域のおかれた状況に即して定 められるべきものであり、中央政府よりも地方公共 団体によって検討されることが多い。

タイ王国における都市計画は、1975年2月5日に公 布された都市計画法によって、その目的を「衛生、 アメニティ、利便性、秩序、美観、不動産の利用、 公共および社会の安全、経済、社会、環境を改善 し、芸術的建築物、歴史的建築物を保全し、自然資 源、景観、その他の自然の恵みを守ること」とし、

「都市総合計画、特定計画を準備、作成、実施する こと」として定義されている。

都市総合計画は「都市計画の目的を達成するため に、都市、都市関連地域、地方部において行われる 不動産の利用、通信、交通、公共施設、環境に関連 する分野の整備、開発、保全のガイドラインとして 用いられる計画、政策、事業であり、一般的な規制 手段を有する」と定義されている。特定計画は「都 市計画をより効果的にするために、都市、都市関連 地域、地方部の特定の地域を整備、開発、保全する ための計画、事業である」と定義されている。

都市計画策定の主体については、「地方政府また は内務省都市農村計画局が都市総合計画および特定 
計画を策定することができる」と規定されている。 しかし、主要な都市部について既に都市総合計画が 策定されているにもかかわらず、現在の地方政府が 都市計画策定業務に耐える体力を持ち得ていないと いう判断に基づき、ほとんどが内務省都市農村計画 局（すなわち中央政府）によって策定されている。 わずかにバンコク首都圈においてのみ、地方政府で あるバンコク首都県庁による都市総合計画の改訂 (都市総合計画は、 5 年に 1 度、定期的に改訂され るように規定されている）が進行中である。また、 特定計画についてはいまだに策定事例がないもの の、バンコク首都圈東部において 2 地区で内務省都 市農村計画局による策定作業が進行しており、今 後、適用が増えていくものと考えられる。

したがって、タイ王国における都市計画は、

・他の国における地方分権型と異なり、中央集権 型の構造を持っている。

・これから特定計画の策定という詳細性を要求さ れる段階を迎える過渡期にある。 ということができる。

そこで、以下、本稿においては、現在のタイ王国 において都市計画策定の中心的な主体である内務省 都市農村計画局を中心に、地方政府の例としてバン コク首都圈庁、アカデミックな主体としてチュラロ ンコン大学を取り上げ、各々の都市計画における GISの活用状況について報告する。

\section{3. 内務省都市農村計画局におけるGISの活用状況}

3.1. 内務省都市農村計画局について

内務省都市農村計画局(Department of Town and Country Planning: DTCP)は都市計画を所管してお り、関連して民生用に $1 / 4,000$ の地形図を所管してい る。尚、陸軍の調査局(Royal Survey Department: RSD)が軍事用に1/15,000の地形図を所管しており、 主体が異なることから、これらの縮尺の異なる地形 図の間でのデータの整合性をとることがこれまでは 難しかったが、1995年8月から両者の間でデータの 共有が開始されている。

また、1995年当初にタイ全土の約7,000の市町村 に対して都市計画を策定することが決定しており、
そのための地形図を毎年1,000地区程度作成すること となっている。

\subsection{GIS導入の目的}

DTCPにおけるGIS利用の目的は以下の2点に集約 することができる。

1)都市計画策定技術の向上

2)情報公開

1)については、約7,000の市町村に対する都市計画 の策定を、短期間に限定された人員(各地方に有る支 所のスタッフを含め、DTCP全体で約700名)によって 実施しなければならないために、業務の効率化が要 求されている。したがって近年進展の著しいコン ピュータ技術の活用、すなわちGISの導入が不可欠 である。

2)については、公的機関へは無償、私企業等へは 有償が基本方針として決まっている。その際には、 現在DTCPで取り扱っている都市計画関連データ(後 述)を更に拡充したいという意向が有る。

\section{3.これまでの経緯}

GIS導入の契機は国際協力事業団とのプロジェク トによってもたらされている。最初に1987年から実 施された国際協力事業団のプロジエクト「都市計画 の応用技術」(日本側の受入機関は建設省住宅局)で 都市計画におけるデータベース利用について言及さ れている。その成果を受けて1990年から実施された 国際協力事業団のプロジエクト「土地利用及び建築 用途規制の方法論に関する研究協力事業」（日本側 の受入機関は建設省建築研究所) でGIS(ARC/NFO) を試験的に導入し、バンコク市内の 21 地区に対して 行われた現地調查の結果を分析するのに活用され た。

その後、1991年にタイ国内の主要GISベンダーに よるコンペが実施されているが、その際に、ARC/ INFOのベンダーから都市部 $(1 / 4,000)$ と農村部 (1/ 15,000）の縮尺を分けて地図を作成することが提案 され、採用されている。これは、タイ全土を同一の 1/4,000の縮尺で作成する場合の費用やデータ量など を考慮し、詳細な検討が必要となる都市部において 
のみ精度の高いデータを作成するようにしたもので ある。

\section{4. 体制}

これまでGIS関連のDTCPの体制としては、地図部 の下に地図課と調査課があり、地図課では地図の作 成・収集、調査課では基準点の設置、都市計画関連 データ（特に土地利用関係）の作成を行ってきた。 しかし、業務の拡大に伴って、都市計画データの収 集とGIS化およびデータ公開の準備を行うため、 1995年に情報センターを設膡し、積極的なGISの活 用を目指している。

\section{5. 利用環境}

利用しているソフトウェア環境は、ARC/INFOを メインにし、MapInfoとArcviewを組み合わせて一般 ユーザー用に利用している。特に地図作成用システ ムとしては、地図のデジタイズなどのデータ取得に AutoCADを、そしてスキャナなどによって取り込ま れたラスターデータをベクターデータに変換するた めにVR Maxを使用している。

ハードウェアとしては、Sun Microsystems社製 ワークステーションを5台とX端末10台、Silicon Graphics社製ワークステーション1台を利用している が、同時にCompaq社製パーソナルコンピュータ 120 台を使ってMicrosoft Windows NTによるパソコン用 ネットワークをも構築している。

\section{6. データ}

現在、DTCPでGIS上で扱っているデータは以下の 通りである。

・1/4,000の精度を持つ地形図

- $1 / 15,000$ 精度を持つ地形図（事実上タイの標 準データ)

-土地・建物利用の現況

- 土地利用規制

これらに加え、将来的には人口、居住に関するも の（タイ全土を対象とした Population Census, Housing Census等は既に実施されている）や土地台 帳なども、このデータに統合したいという意向が有
る。

\section{7. 教育}

現在、DTCPにおけるGIS関連の教育体制は、一般 的なパソコンの基礎的なものからGIS専門家として の高度なものまで、以下の3段階のシステムとなつ ている。

1)DTCP内で実施されるもの

2)国内企業や大学の研修コースへの参加

3)海外への派遣

1)は基礎的なコースであり、初歩から基礎的な文 書作成、CAD(Computer Aided Design)、GISまでを 範疇に入れている。しかしながら、すべてをDTCP 職員全員が受講するわけではなく、専門性が高くな るにつれて受講の対象となる人数も減少するしくみ となっている。これまでのところ、初歩 : 約 200 名、文書作成 : 約 150 名、CAD : 約 50 名、GIS : 約 30名が受講の実績である。2)、3)は非常に専門性が 高いため、対象人数が更に減少する。

また、講習の効果を高めるために、内規として 「必要となるレベルのコースを受講していること」 を昇進の要件として定めている。

この教育システムが実施されてまだ日が浅いた め、これまでのところ海外派遣者はいないなど、そ の効果を評価するのは難しいが、「DTCP職員がコ ンピュータを使い始めたという意義が大きい」とい う。

\section{8. 今後の予定}

地形図の作成に関して、GPS(Global Positioning System)が導入され、得られるデータの精度と応答 性の向上のための地上固定局が以下の2 Phaseの計画 によって設置されている。

Phase 1 （1995年）：5県

Phase 2 （1996年）：8県（3増）

Phase 2 終了時には、タイ全土が地上固定局の圈 域でカバーされ1秒間の測定で1 $\mathrm{m}$ 誤差の位置デ一 タを得ることができる予定であり、これまで航空写 真のみから作成されていたデー夕作成の効率と精度 の向上が期待される。また、これまであいまいのま 
ま残されていた一部の地方公共団体の境界の確定に もGPSの活用が期待されている。

今後のDTCPを考えた場合には、これまで実施し てきた業務と並んで「都市計画関連のGISデータの 公開」という新たな業務の重要性が極めて大きくな ることが予想される。特に、詳細なデータは有償に するが、概要的な大まかなものはインターネットな どを通じて無償で公開することも検討しているとい うことであり、大きな期待が奇せられている。

また、従来から行われている「地形図の作成」や 「都市計画の策定」といつた業務へのGISの活用に より、業務の効率化、高度化の進展が期待されてい る。

\section{4 . バンコク首都圈庁におけるGISの活用状況}

4.1. バンコク首都圈庁について

前述の通り、バンコク首都圈庁 (Bangkok Metropolitan Agency: BMA)は、タイ王国で唯一、自 ら都市計画を策定している地方公共団体である。そ のため、日本や欧米諸国から、専門家の派遣を始め とする都市計画関連の技術移転が積極的に行われて おり、GISそのものについても、オーストラリアか らの専門家を受け入れている。

\subsection{GIS導入の目的}

BMAにおけるGIS導入の目的は、主として都市計 画閶迪の情報の贤集、管理、活男および他機関との交 換にある。しかし、これに留まらず、多方面への応 用なども試みられている。特にバンコク首都圈は チャオプラヤ川の流域にあたるため、雨季の終わり には洪水による被害が発生することが多く、治水や 洪水制御への活用は重要な関心事である。また、深 刻な交通渋滞の解消に向けた利用についても期待が きわめて大きい。

\section{3. 経緯}

これまでの経緯としては、1990年から3 か年に 渡って、BMA、電話公社、電力公社、水道公社、土 地公社が協力してGISに関するパイロットスタディ を実施している。
対象データは以下の通りである。

・行政界

-土地利用計画

·建物

- 地形

・水系

・インフラ(上下水道、電気、電話)

・交通(道路、鉄道)など

すべてのデータはBMAによって供給された1/ 1,000の地形図上に統合された。そのうち、データが 作成された対象地域 $25 \mathrm{~km}^{2}$ 中の $3 \mathrm{~km}^{2}$ に対してGIS データベースが作成され、評価が塞施された。

しかし母体によって使用目的が大きく異なるため に必要となる出力も違い、プロジェクト終了時に残 念ながら決裂してしまった。そのため、BMAが独自 に開発をつづけることとなり、現在はBLIS(Bangkok Land Information System)として整備されている。

\section{4. 現状}

BMA内の関連部局としては都市計画局に土地情報 課と地図調査課がある。

土地情報課はGISを専門的に扱う部署であるが、 1995年8月に政策局から都市計画局に移っており、 扱う内容が政策関連情報から都市計画関連情報へと 変化した。地図調查課は実際に対処となる地域での 情報収集や地図の作成を業務としており、今のとこ ろGISを積極的に利用しているわけではないように 見受けられる。

扱うデータについては、現在想定している利用の 主目的が下水等の施設管理のため、前述のDTCPが 作成する $1 / 4,000$ の精度を持つデータではなく、1/ 1,000地形図を基に公図や建物などに関する情報の統 合を目標としている。現状としてはデジタル化済み の市販の $1 / 20,000$ 地形図を利用し、行政界、道路 （高速道路、主要道路、側道）、川、運河、鉄道の データが利用可能となっている。

利用環境は、ソフトウェアとして1991年にARC/ INFOを導入している。当初はGISそのものの有効性 を検討していたが、現在では下水道などへの応用を 検討している。ハードウェアとしてはSun 
Microsystems社製ワークステーションを 9 台、IBM 社製パーソナルコンピュータを 6 台利用している。

\section{5. 課題}

これからの課題として第 1 は、BLISを主に利用し ている土地情報課が都市計画業務を扱うようになつ てから日が浅い（ヒアリング調查時点で約 3か月） ため、システムの都市計画への活用についてまだ方 針が定まっていないことが挙げられる。

2 点目の課題として挙げられるのは教育である。 現在、土地情報課においてBLISを利用しているス タッフは既にGISの利用者として必要な知識、経験 を有しており、これからの技術的に高度な利用が期 待できる。しかし都市計画策定の担当者などの教育 が必要となる新規ユーザーまで利用が普及していな い。逆に土地情報課においては、前述の通り、都市 計画についての知識、経験がいまだ浅いと言わざる をえない。

したがって今のところ大きな問題になっていない が、GISの専門家への都市計画の教育と都市計画の 専門家へのGISの教育の双方が共に今後の大きな課 題となることが予想される。

以上のように、まだまだ課題は残されているが、 BLISは実際の都市計画策定に利用されるシステムで あり、地方政府が自ら詳細な都市計画を策定するた めのツールとして利用されることが期待できる。今 後のシステムの進展と活用状況に注目すべきであろ う。

\section{5. チュラロンコン大学}

5.1. チュラロンコン大学について

チュラロンコン大学はバンコクの中心市街地にあ り、トップクラスにランクされている、理工系学科 を中心とした総合大学である。この大学では理学部 を始め、建築学部などでもGISを扱っているが、今 回は工学部調査工学科での都市計画への活用状況に ついてヒアリングを行った。

\section{2. 現状と問題点}

これまで、政府からの委託研究として、GISの都
市計画への活用を行ってきた。内容としてはデータ の作成が多いが、土地利用類型の自動認識のために 必要な情報の検討なども行っている。

GISに関連して、コーンケン大学、ソンクラー大 学、チェンマイ大学にGPSの地上固定局が敷設され ている。しかし、GPSのメーカ一間の情報の互換 性、24時間運用されることに伴う莫大な量のデータ の処理・保管などが問題となっている。

\section{6. まとめ}

本稿においては夕イ王国におけるGISの都市計画 への利用状況について報告した。

タイ王国における都市計画はいまだ発展途上の段 階にあり、これからの状況の変化は予断を許さな い。地方政府主体の都市計画の導入および詳細な都 市計画の検討は今後避けられないものと考えられ る。また、これらの作業に必要なデー夕は、精度が 十分ではない、あるいはそもそもデータを得るため の調查が行なわれていないなど、の状況にあり、今 後の整備を待たなければならない。

しかしながら、GISに限っていえば、これまで計 算機のハードウェア、ソフトウェア、データの資産 に乏しかったことがかえって束縛される条件を少な くし、先進国と同様またはそれ以上の性能をもつ最 新の計算機とソフトウェアを導入される結果をよん でいる。また、わが国を始めとする先進国のGISの 利用のノウハウを積極的に受け入れる体制にあり、 最新の技術を貪欲に吸収している。

今後、咀嚼された最新の技術を基にGISデータが 質・量ともに整備され、必要な地域をカバーすると 同時に、特定計画に留まらない詳細な都市計画の検 討に耐えられるものとなることが期待される。

またGISデータの公開に向けて、DTCP、RSDなど の関係各機関が努力しており、これまで地図に関す るデータが軍事的な側面から厳重に保護されてきた ことを考えれば、注目に值する。 今後のタイ王国でのGISの発展に期待したい。

\section{謝辞}

今回のヒアリング調査にあたり、Mr. Charasroj 
Bothadamrih (DTCP), Dr. Peerapong Sirikasem (BMA), Mr. Tony Edwards (EC/BMA), Dr. Sukit Viseshsin (Chulalongkorn University)、村井俊治教授(Asian Institute of Technology：当時)の貴重な協力を頂い た。また、タイ王国の都市計画関連制度については 村主英明氏（建設省）、亀村幸泰氏（国際協力事業 団在夕イ長期専門家：当時）の協力を頂いた。ここ に記して感謝の意を示したい。 